Uden, N. van \& L. Do Carmo Sousa. (1957). J. gen. Microbiol. 16, 385-395

\title{
Yeasts from the Bovine Caecum
}

\author{
By N. vaN UDEN AND LIDIA DO CARMO SOUSA \\ Department of Mycology, Botanical Institute, University of Lisbon, Lisbon, \\ Portugal
}

SUMMARY : From the caeca of 252 adult bovines 131 yeast strains were isolated, distributed as shown (in brackets) among the following species: Saccharomyces cerevisiae (12), S. chevalieri (3), S. drosophilarum (3), S. fragilis (1), Pichia bovis (1), P. membranaefaciens (3), P. fermentans (3), Cryptococcus diffluens (1), Torulopsis glabrata (4), Torulopsis sp. (2), Candida tropicalis (45), C. parapsilosis (3), C. krusei (33), C. macedoniensis (1), C. utilis (1), C. bovina (1), Trichosporon cutaneum (5). Candida albicans was not isolated. The apparent absence of $C$. albicans from the bovine intestinal tract may explain the rareness of oral and intestinal moniliasis in bovines. Infection in certain forms of yeast mastitis (caused neither by C. albicans nor by Cryptococcus neoformans) may be derived from the intestinal tract.

Descriptions and Latin diagnoses of Pichia bovis n.sp. and Candida bovina n.sp. are given.

Knowledge of the intestinal yeast flora of man and animals has both ecological and medical importance. Some of the more important ecological aspects so far brought to light may be summarized as follows. Certain yeasts have their principal habitat in the human or animal digestive tract and have never, or only exceptionally, been found outside the human or animal body. Within this group several species can be isolated from many different animals (Candida albicans, Torulopsis glabrata, etc.), while others seem peculiar to a few host species (Saccharomycopsis guttulata, Torulopsis pintolopesii, etc.). A second group is constituted by yeasts which have their natural habitat on a wide variety of substrata including the human and animal digestive tract (Candida tropicalis, C. krusei, Trichosporon cutaneum, etc.). The third and by far the largest group contains yeast species which are not true inhabitants of the digestive tract, but which may remain viable for some time after entering the digestive tract with food or otherwise (Saccharomyces cerevisiae and many others).

From the medical and veterinary point of view knowledge of the intestinal yeast flora of man and animals is highly desirable, as it may elucidate the mechanisms of infection and re-infection in certain yeast diseases. It is now clear, for example, that moniliasis of man and certain birds is an endogenous mycosis, i.e. the causative yeasts (mostly Candida albicans, rarely C. tropicalis or others) live saprophytically in the digestive tract and may, under special conditions, invade various organs and cause disease.

In the present study an attempt has been made to determine the bovine intestinal ycast flora for a double purpose: (1) to contribute to the knowledge of the ecology of human and animal yeasts; (2) to obtain information on the possible relationship between the bovine intestinal yeast flora and bovine yeast diseases, particularly yeast mastitis. 


\section{METHODS}

Two hundred and fifty-two adult bovines were sampled in the abattoir of Lisbon. Immediately after evisceration a small area of the surface of the caecum was cleaned with ethanol and incised with flamed scissors. Then a loopful of faecal material was inoculated in a tube containing broth of the following composition: glucose, $2 \%$; yeast extract (Difco), $0.5 \%$; peptone, $1 \%$; distilled water. To limit bacterial growth 50 units penicillin $/ \mathrm{ml}$. and 100 units streptomycin $/ \mathrm{ml}$. had been added to the broth. To exclude all yeasts which do not thrive at body temperature and therefore cannot be considered intestinal inhabitants, the tubes were incubated at $37^{\circ}$. Within 3-5 days most tubes showed growth of filamentous fungi, mostly species of the genera Aspergillus, Mucor, Rhizopus and Absidia. As the conidia and sporangiospores of these fungi would make it very difficult to isolate any yeasts present in the broth, plating out was done before sporulation occurred, generally about 4 days after inoculation. A loopful of the broth was streaked on plates of the following medium: glucose, $2 \%$; yeast extract (Difco), $0.5 \%$; peptone, $1 \%$; agar, $2 \%$; distilled water. To discourage bacterial growth the medium was adjusted to $\mathrm{pH} 3.5$ with lactic acid. The plates were incubated at $37^{\circ}$. From each type of yeast colony which appeared on the plates a single one was isolated and, when necessary, purified by plating or passage through media containing antibiotics.

The isolated yeasts were classified according to the system of Lodder \& Kreger-van Rij (1952). A few isolates could not be identified with species recognized by Lodder \& Kreger-van Rij or with species described after the appearance of Lodder \& Kreger-van Rij's monograph; some of them are described in this paper as new entities; others continue under study. In all cases, where doubts arose, our strains were compared with type strains obtained from the Yeast Division of the Centraalbureau voor Schimmelcultures, Delft, Holland.

The properties of the yeasts were studied by the following methods:

Growth in liquid medium. According to Lodder \& Kreger-van Rij (1952) but with the following medium: glucose, $2 \%$; yeast extract (Difco), 0.5\%; peptone, $1 \%$; distilled water.

Appearance on streak culture. After 30 days at $\pm 25^{\circ}$ on the following medium: glucose, $2 \%$; yeast extract (Difco), $0.5 \%$; peptone, $1 \%$; agar, $2 \%$; distilled water.

Formation of pseudomycelium. On Dalmau plates (Wickerham, 1951) using the same medium as for the streak culture. In doubtful cases potato glucose agar (Difco) or corn meal agar (Difco) were also used.

Sporulation. According to Lodder \& Kreger-van Rij (1952).

Fermentation. Glucose, galactose, sucrose, maltose and lactose fermentations according to Wickerham (1951); raffinose according to van Uden (1956).

Assimilation. According to Wickerham's (1951) technique. The following compounds were used: D-glucose, D-galactose, sucrose, maltose, lactose, raffinose, L-arabinose, D-xylose, ethanol, glycerol, D-mannitol, D-sorbitol, inositol, inulin, soluble starch, potassium nitrate. 


\section{RESULTS}

One hundred and thirty-one isolates belonging to six genera and seventeen species were obtained; two isolates are described here as new species, and two others continue under study (Table 1). Findings divergent from species descriptions in Lodder \& Kreger-van Rij's monograph or from descriptions of more recent species are given below. As in the published descriptions of most species the assimilation of only six or seven compounds is considered, account is given here of the assimilative properties of our bovine strains and some type strains toward the sixteen compounds we have been using (Table 2).

Table 1. Yeasts isolated from the caeca of 252 bovines

\begin{tabular}{|c|c|c|c|}
\hline Species & $\begin{array}{c}\text { Number } \\
\text { of } \\
\text { strains }\end{array}$ & Species & $\begin{array}{c}\text { Number } \\
\text { of } \\
\text { strains }\end{array}$ \\
\hline $\begin{array}{l}\text { Saccharomyces cerevisiae } \\
\text { Hansen }\end{array}$ & 12 & $\begin{array}{l}\text { Candida tropicalis (Castellani) } \\
\text { Berkhout }\end{array}$ & 45 \\
\hline S. chevalieri Guilliermond & 3 & C. parapsilosis (Ashford) & 3 \\
\hline S. drosophilarum El Tabey & 3 & Langeron \& Talice & \\
\hline Shehata, Mrak \& Phaff & & C. krusei (Castellani) Berkhout & 33 \\
\hline S. fragilis Jörgensen & 1 & C. macedoniensis (Castellani \& & 1 \\
\hline Pichia bovis n.sp. & 1 & Chalmers) Berkhout & \\
\hline P. membranaefaciens Hansen & 3 & C. utilis (Henneberg) Lodder \& & 10 \\
\hline P. fermentans Lodder & 3 & Kreger-van Rij & \\
\hline Cryptococcus diffluens (Zach) & 1 & C. bovina n.sp. & 1 \\
\hline Lodder \& Kreger-van Rij & & Trichosporon cutaneum (De & 5 \\
\hline $\begin{array}{l}\text { Torulopsis glabrata (Anderson) } \\
\text { Lodder \& de Vries }\end{array}$ & 4 & $\begin{array}{l}\text { Beurman, Gougerot \& } \\
\text { Vaucher) Ota }\end{array}$ & \\
\hline Torulopsis sp. & 2 & & \\
\hline
\end{tabular}

\section{Saccharomyces}

Twelve isolates fitted the descriptions of Saccharomyces cerevisiae Hansen, as given by Lodder \& Kreger-van Rij (1952). L-Arabinose was used weakly by one strain, D-mannitol weakly by another strain. Three isolates were similar to S. chevalieri Guilliermond. According to Lodder \& Kreger-van Rij (1952) $S$. chevalieri differs from $S$. exiguus Hansen, by its bigger cells and its ability to produce a pseudomycelium. As the cells of our strains are slightly smaller than the cells of the type strain of $S$. chevalieri and as they produce only a very primitive pseudomycelium, they were compared with the type strains of $S$. exiguus and of S. chevalieri. No differences in the fermentation and assimilation reactions were observed (Table 2 ). It may be concluded that $S$. chevalieri is closely related to $S$. exiguus.

Three strains were identified with Saccharomyces drosophilarum, a species recently described by El Tabey Shehata, Mrak \& Phaff (1955). Fermentation and assimilation reactions (Table 2), pigment production, type of pseudomycelium and gross morphology were the same in the bovine strains and the type strain. However, the cells of the bovine strains were smaller and measured after $48 \mathrm{hr}$. in broth $(2 \cdot 6-4) \times(3 \cdot 3-5 \cdot 9) \mu$., whereas the cells of the type strain measure $(3 \cdot 3-6 \cdot 6) \times(4 \cdot 6-7 \cdot 3) \mu$. Furthermore, the ascospores of the 
type strain are distinctly kidney-shaped, whereas the spores of the bovine strains were roundish and only rarely somewhat kidney-shaped. We do not think that these minor morphological differences justify the creation of a separate variety for the bovine strains. If, however, by the use of a larger number of compounds physiological differences should be found their separation from the species will have to be considered.

One isolate similar to Saccharomyces fragilis Jörgensen was found but failed to form a pseudomycelium.

Table 2. Assimilation reactions of the bovine strains and some type strains of yeasts

Strains

Saccharomyces cerevisiae (12)

S. chevalieri (3)

S. chevalieri (t.s.)

S. exiguus (t.s.)

S. drosophilarum (3)

S. drosophilarum (t.s.)

S. fragilis (1)

Petasospora rhodanensis (t.s.)

Pichia bovis (1)

P. xylosa (t.s.)

$P$. fermentans (3)

$P$. membranaefaciens (3)

Torulopsis glabrata (4)

Cryptococcus diffuens (1)

Candida bovina (1)

C. guilliermondii (1)

C. krusei (33)

C. macedoniensis (1)

C. parapsilosis (3)

C. tropicalis (45)

C. utilis (10)

C. utilis (t.s.)

Trichosporon cutaneum (5)

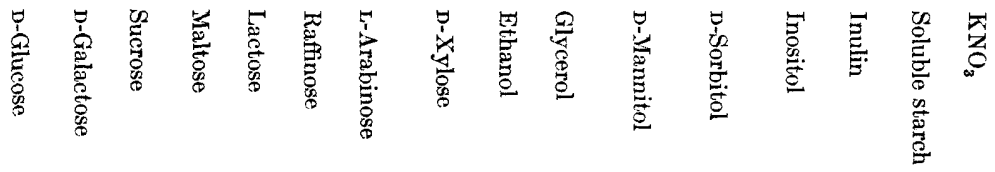

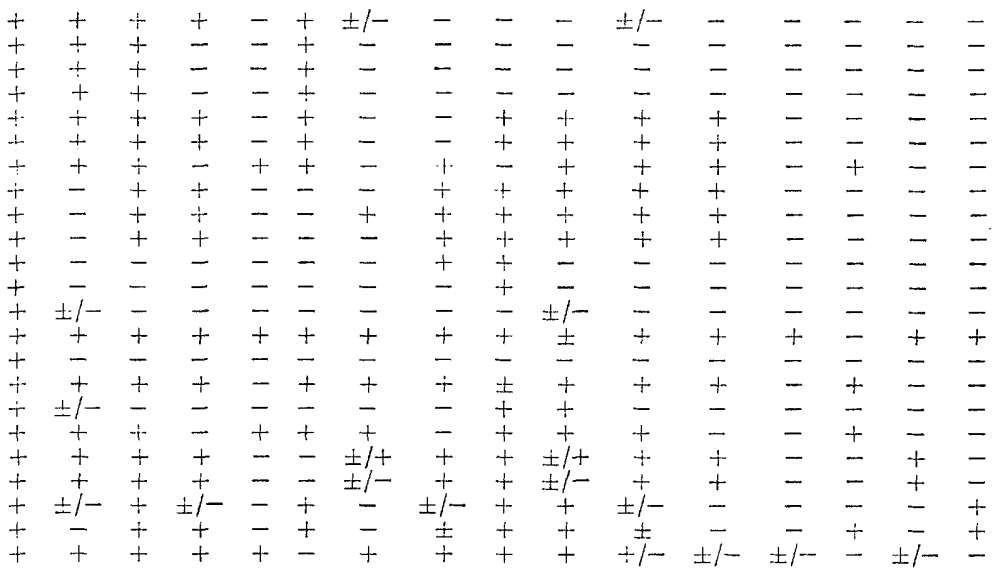

Figures in parentheses are the numbers of bovine strains studied. t.s.=type strain obtained from Centraalbureau or from the author of the species. $+==$ assimilation strongly or moderately positive; $\pm=$ assimilation weakly positive; $-=$ assimilation negative; $+1-=$ assimilation positive in some strains, negative in other strains.

\section{Pichia}

An amended diagnosis of this genus has recently been given by Phaff (1956) to allow inclusion of species characterized by a lack of pellicle formation, by the absence or a very poor pseudomycelium or by a combination of both properties. Boidin \& Abadie (1954) created the genus Petasospora for nitrate-negative species with hat-shaped spores, having no or weak fermentative power, and not forming an early pellicle. Phaff's definition of the genus Pichia allows the inclusion in the latter genus of all species so far described in Petasospora.

One of our bovine isolates resembles the type species of the genus Petasospora, P. rhodanensis (Ramirez \& Boidin) Boidin \& Abadie (1954), as well as Pichia xylosa Phaff, Miller \& Shifrine (1956), and was compared with the type strains of both species. It was found that Pichia xylosa is identical with Petasospora rhodanensis (Table 2). As the latter species was described first, 
the specific epithet rhodanensis has priority. As for the desirability to maintain the genus Petasospora we follow the suggestions of Phaff (1956) and of Kregervan $\mathrm{Rij}$ (personal communication) and will transfer therefore $\boldsymbol{P}$. rhodanensis to the genus Pichia: P. rhodanensis (Ramirez \& Boidin) n.comb., synonym P. xylosa Phaff, Miller \& Shifrine (1956). The bovine strain differs from this species both morphologically (short oval cells and absence of a well-developed pseudomycelium) and physiologically (assimilation of $\mathbf{L}$-arabinose). It is therefore considered to belong to a new species, for which we propose the name Pichia bovis.

\section{Pichia bovis sp.nov.}

In medio liquido cum dextroso et peptono et extracto levedinis cellulae ovoideae, $(2 \cdot 6-3 \cdot 3) \times(3 \cdot 3-5 \cdot 3) \mu$. et $(4-5 \cdot 9) \times(5 \cdot 3-7 \cdot 9) \mu$. aut globosae $(2-4) \mu$., singulares binae aut catenatae; sedimentum et anulus formantur. In agaro peptonato cum dextroso et extracto levedinis cultura flavo-albida, mollis, nitens, glabra. Pseudomycelium nullum. Ascosporae pileiformis, 1-4 in asco. Glucosum fermentatur at non galactosum, saccharum, maltosum, lactosum, raffinosum. Assimilat dextrosum, saccharum, maltosum, arabinosum, xylosum, alcohol aethylicum, glycerinum, mannitol, sorbitol, non vero galactosum, lactosum, raffinosum, inositol, inulinum, amidum et nitras kalii.

In liquid medium after $48 \mathrm{hr}$. three types of cells are seen: small oval $(2 \cdot 6-3 \cdot 3) \times(3 \cdot 3-5 \cdot 3) \mu$.; big oval $(4-5 \cdot 9) \times(5 \cdot 3-7 \cdot 9) \mu . ;$ round $(2-4) \mu$.; they are single, in pairs or in small groups (Fig. $1 a)$; a sediment and a ring are formed. The streak culture is cream-coloured, soft and smooth with a shining surface. No pseudomycelium is formed, only a few short chains of oval cells are seen
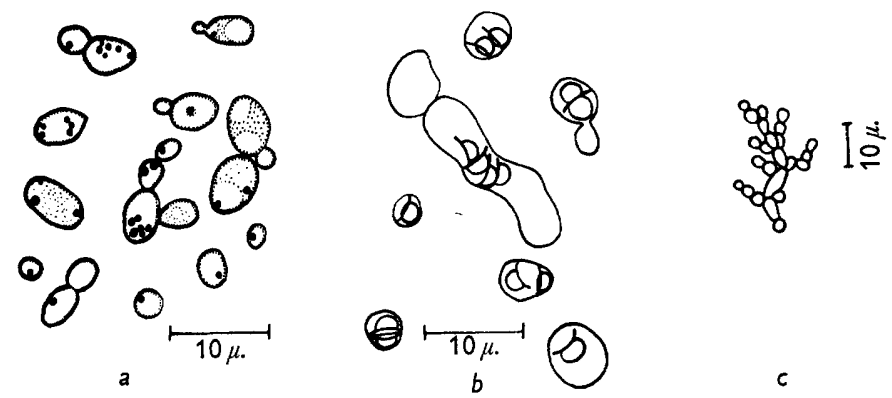

Fig. 1. Pichia bovis. $a$, organisms after $48 \mathrm{hr}$. in broth; $b$, asci and ascospores; $c$, short chains as seen in Dalmau plates. Camera lucida drawings.

(Fig. 1c). In young cultures iso- and heterogamic conjugation occurs. Asci derive from diploid cells and contain 2-4 hat-shaped spores (Fig. 1b). Glucose is fermented; galactose, sucrose, maltose, lactose and raffinose are not fermented. Assimilates glucose, sucrose, maltose, L-arabinose, D-xylose, ethanol, glycerol, mannitol, sorbitol. Not assimilated are galactose, lactose, raffinose, inositol, inulin, soluble starch and potassium nitrate.

Three sporulating, non-fermenting strains were identified with Pichia membranaefaciens; besides glucose and ethanol no other compounds were 
utilized (Table 2). Three strains fit well in Lodder \& Kreger-van Rij's description of $P$. fermentans; it is remarkable that all three assimilate $\mathrm{D}$-xylose (Table 2).

\section{Cryptococcus}

One strain was identified with Cryptococcus diffluens. Growth at $37^{\circ}$ was slow; many compounds were assimilated (Table 2).

\section{Torulopsis}

Four strains were identical with Torulopsis glabrata; besides glucose, galactose and glycerol were sometimes weakly assimilated. Two strains belonging to this genus continue under study.

\section{Candida}

Forty-five strains belonged to Candida tropicalis. Besides glucose, galactose, sucrose and maltose, D-xylose, ethanol, mannitol, sorbitol and soluble starch were assimilated (Table 2). The assimilation pattern of $C$. parapsilosis is almost the same; three strains were identified with the latter species. C. krusei was isolated thirty-three times, $C$. macedoniensis once and $C$. utilis ten times. All ten strains of $C$. utilis assimilated glucose, sucrose, raffinose, ethanol, glycerol and nitrate; the assimilation of galactose, maltose, D-xylose and mannitol was variable; none assimilated inulin whereas the type strain does. The ten bovine strains and the type strain showed the same fermentation reactions and morphology.

One strain was considered to belong to an undescribed species, for which we propose the name Candida bovina. As this strain produced a pseudomycelium, we had to place it in the genus Candida. We think, however, that C. bovina is closely related to the thermophilic yeast Torulopsis pintolopesii, from which it differs by its bigger cells, its ability to grow at room temperature, the formation of pseudomycelium and probably its habitat. We consider the generic separation of Candida bovina and Torulopsis pintolopesii a provisorium awaiting a future more natural system of classification for the yeasts now placed in the genera Torulopsis and Candida.

\section{Candida bovina sp.nov.}

In medio liquido cum dextroso et peptono et extracto levedinis cellulae ovoideae aut longovoideae $(4-5 \cdot 9) \times(5 \cdot 9-9 \cdot 9) \mu$., binae aut singulares, sed communiter in catenis ramosis; sedimentum formatur, anulus pelliculaque non oriuntur. In agaro peptonato cum dextroso et extracto levedinis cellulae globosae (4.6$9 \cdot 9) \mu$., ovoideae $(4 \cdot 6-5 \cdot 9) \times(5 \cdot 3-7 \cdot 3) \mu$. et irregulares; cultura flavido-albida, mollis, nitens, glabra. In agaro farinae mais pseudomycelium abundat. Cellulae pseudomycelii et blastosporae longovoideae aut oblongae in catenis ramosis. Fermentat dextrosum, non vero galactosum, saccharum, maltosum, lactosum neque raffinosum. Assimilat dextrosum. Galactosum, saccharum, maltosum, lactosum, raffinosum, arabinosum, xylosum, alcohol aethylicum, glycerinum, mannitol, sorbitol, inositol, inulinum, amidum et nitras kalii non assimilantur. 
In liquid medium after $48 \mathrm{hr}$. cells are oval and long oval, $(4-5 \cdot 9) \times(5 \cdot 9-$ $9 \cdot 9) \mu$, single, in pairs, but mostly in groups (Fig. $2 a$ ). No ring or pellicle but a sediment is formed. On solid medium cells are round $(4 \cdot 6-9 \cdot 9) \mu$, oval $(4 \cdot 6-$ $5 \cdot 9) \times(5 \cdot 3-7 \cdot 3) \mu$. and irregular (Fig. $2 b$ ). The streak culture is cream-coloured, soft and smooth with a shining surface. On corn meal agar pseudomycelium formation is abundant. It consists of dense, much ramified chains of oval and cylindrical cells (Fig. 2c). Only glucose is fermented and assimilated. No assimilation of galactose, sucrose, maltose, lactose, raffinose, arabinose, xylose, ethanol, glycerol, mannitol, sorbitol, inositol, inulin, soluble starch and potassium nitrate.
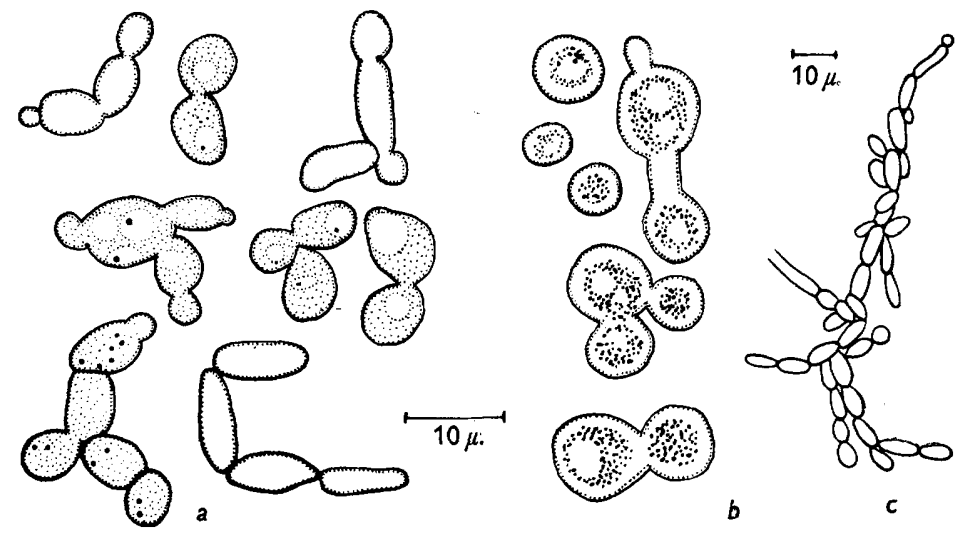

Fig. 2. Candida bovina. a, organisms after $48 \mathrm{hr}$. in broth; $b$, after 12 days on solid medium; $c$, pseudomycelium as seen in Dalmau plates with corn meal agar. Camera lucida drawings.

\section{Trichosporon}

Five strains were identified with Trichosporon cutaneum as described by Lodder \& Kreger-van Rij (1952). Two strains used mannitol, sorbitol and inositol but not soluble starch; the three other strains assimilated soluble starch but did not use mannitol, sorbitol or inositol. The type strain obtained from the Centraalbureau has become pleomorphic and results of assimilation reactions were uncertain. It is felt that the species $T$. cutaneum is heterogenic and further research on this subject is needed.

\section{DISCUSSION}

The most important single fact among our results seems to be the apparent absence of Candida albicans from the bovine intestinal tract. $C$. albicans belongs to a group of yeasts which may be called obligate saprophytes of warmblooded animals having its normal habitat in the digestive tract of man and various other animals. Although normally a harmless saprophyte, this yeast may cause under special conditions disease of man, birds and other animals ('moniliasis'). According to different authors $14-30 \cdot 8 \%$ of humans harbour Candida albicans in their faeces (Benham \& Hopkins, 1933; Schnoor, cited by Yo Bwan Hie, 1954; Lawler et al., cited by Yo Bwan Hie, 1954; Marples \& 
Di Menna, 1952). Of 378 fowls studied by Jordan (1953) $21 \%$ harboured C. albicans in the crop. C. albicans has been isolated from turkeys suffering from moniliasis (Blaxland \& Fincham, 1950). According to Skinner (1947) C. albicans has been recorded in laboratory animals, rats, pigeons and the European hedgehog. Coutelen \& Cochet (1942) reported the isolation of C. albicans from rabbit, guinea-pig and rat; Talice (1932) referred to its isolation from fowl, a lamb, a cat, a dog, a turkey and donkeys. Only exceptionally can $C$. albicans be isolated from non-animal sources and there is no evidence that $C$. albicans has a natural habitat outside the human and animal body (Negroni \& Fisher, 1941; Di Menna, 1955; van Uden, Matos Faia \& AssisLopes, 1956). It would seem from our results, however, that the bovine intestinal tract does not constitute a natural habitat for $C$. albicans.

Torulopsis glabrata, another obligate saprophyte of warm-blooded animals, was found four times in our series. The potential pathogenicity of this species is very small; histopathological pictures suggestive of histoplasmosis may be produced in experimental infections of rats and mice (Lopez Fernandes, 1952). All ten strains studied by Lodder \& Kreger-van Rij (1952) were of human origin; numerous strains were isolated by ourselves from human faeces and from the vagina and once we isolated a strain from the liver of an elephant. The only known isolation of $T$. glabrata outside the human or animal body was the one of Phaff, Mrak \& Williams (1952) who isolated a strain from the surface of iced shrimps.

Candida bovina is also most probably an obligate saprophyte of warm-blooded animals. Torulopsis pintolopesii, to which it seems nearly related, is highly adapted to life in warm-blooded animals and does not grow at room temperature; it was originally isolated from white mice (van Uden, 1952). Since then it has been isolated from mice, rats, pigeons and meadow voles (Artagaveytia-Allende, 1953; Parle [personal communication of Di Menna]; Aschner, Halevy \& Awram, 1954; Emmons, personal communication). Further research with a more exhaustive isolation technique is needed to verify the incidence of Candida bovina. This yeast is somewhat fastidious and may easily be overgrown by more vigorous species during isolation procedures.

A second group of yeasts, which may be called facultative saprophytes of warm-blooded animals, is composed of yeasts which live naturally both inside and outside the body; Candida tropicalis and C. krusei belong to this group. Both species are frequently encountered and have been isolated from man and other animals as well as from materials such as beer, brewery yeast, dough, fruit, kefir, fodder yeast, tea fungus (Lodder \& Kreger-van Rij, 1952). It would seem from our results that both $C$. tropicalis and C. krusei are dominant species in the bovine intestinal yeast flora. Of the two, only C.tropicalis is a potential pathogen; it is less virulent than C. albicans (Mackinnon, 1936). Trichosporon cutaneum belongs to the same group, together with Candida parapsilosis, C. guilliermondii and $C$. macedoniensis. With the possible exception of some strains of Trichosporon cutaneum none of them has pathogenic properties.

The incidence of Candida utilis (10 strains) is relatively high. This species is 
used for the manufacture of fodder yeast in many countries (White, 1954), but to the best of our knowledge no fodder yeast of this kind is used in Portugal. It may well be that $C$. utilis is not a simple intestinal passer-by introduced with food but a facultative saprophyte of bovines and probably of other warmblooded animals. The fact that two of Lodder \& Kreger-van Rij's strains were isolated from human sputum supports this view.

Before something can be said of the ecological behaviour of Pichia bovis more strains will have to be isolated.

The other species isolated from our bovine series probably belong to a third group of yeasts which do not live saprophytically in the digestive tract but come principally from ingested food. Ecologically well-known yeasts, e.g. Saccharomyces cerevisiae and $S$. chevalieri, may be placed without reserve into this group. Also Cryptococcus diffuens surely is not an intestinal saprophyte as it thrives very badly at $37^{\circ}$. With other species, e.g. Pichia membranaefaciens and $\boldsymbol{P}$. fermentans, some doubt may arise about their ecological classification.

From the veterinary point of view our results throw some light on bovine yeast diseases. Thrush or moniliasis of the mouth and intestine seems to be rare in bovines. According to Skinner (1947) it was stated by Hagan: 'Some authors refer to monilia infections of the oral mucosa in calves and colts. No additional information about them is available. Presumably they are of little consequence.' Our findings that the common cause of moniliasis, Candida albicans, is substituted in the bovine intestinal yeast flora by the much less virulent $C$. tropicalis might partly explain the apparent rareness of thrush in bovines. Yeast infections of the udder, however, seem to be more frequent. A severe form is caused by Cryptococcus neoformans and epizootics of this type have been reported by Pounden, Amberson \& Jaeger (1952) and by Simon, Nichols \& Morse (1953). So far C. neoformans has not been found as a saprophyte in the human or animal digestive tract, but has been isolated from soil (Emmons, 1951; Ajello, 1956), from pigeon nests and dung (Emmons, 1955) and from a Dentroctonus beetle (Shifrine \& Phaff, 1956). In our series of 252 bovines no strain of $C$. neoformans was isolated. It would seem therefore that C. neoformans mastitis is an exogenous mycosis. The same cannot be said of the other form of yeast mastitis which normally is fairly mild, occurs sporadically or in small epizootics and is caused by various yeast species. Cases have been reported by Rolle (1934), Murphy \& Drake (1947), Lernau, Shapiro \& Aschner (1947), Stuart (1951) Burkey, Burkner, Underwood \& Swett (1951). From these cases not fully-identified yeasts of the genera Trichosporon and Pichia have been isolated. Stuart (1951) isolated a Candida sp. different from C. albicans; Murphy \& Drake (1947) reproduced the disorder experimentally with a strain of Trichosporon sp. isolated from a case of mastitis. So far Candida albicans does not seem to have been isolated from cases of yeast mastitis; this may be related to the apparent absence of $C$. albicans from the bovine intestinal tract. On the other hand, since we isolated from the bovine intestinal tract species of the genus Candida other than C. albicans, as well as species of Pichia and Trichosporon, the possibility must be kept in mind that infection in yeast 
mastitis, not caused by Cryptococcus neoformans, may originate from faecal material.

Cultures of Pichia bovis n.sp. and Candida bovina n.sp. have been deposited with the Yeast Division of the Centraalbureau voor Schimmelcultures, Delft, Netherlands.

This work was subsidized by the 'Direç̧ão Geral dos Serviços Pecuários', Department of Agriculture, Lisbon, and by the 'Instituto de Alta Cultura', Lisbon.

The authors are much indebted to Dr W. Slooff and Dr N. J. W. Kreger-van Rij of the Centraalbureau for an opportunity to discuss the identity of Pichia bovis and Candida bovina.

Thanks are due to Dr Romeiras and Dr Leitão who have kindly permitted the sampling of bovines in the abattoir of Lisbon.

\section{REFERENCES}

AJEllo, L. (1956). Soil as natural reservoir for human pathogenic fungi. Science, $123,876$.

Artagaveytia-Allende, R. C. (1953). Sobre una levadura hallada en el peritoneo de ratones inoculados con diversos materiales. Arch. Soc. Biol. Montevideo, $20,1$.

Aschner M., Halevy, S. \& Awram, D. (1954). The yeast-flora of rats on normal diets and on diets supplemented with antibiotics. Bull. Res. Coun. Israel. 4, no. 2.

Benham, R. W. \& Hopkins, A. M. (1933). Yeast-like fungi found on the skin and in the intestines of normal individuals. Arch. Derm. Syph., N.Y. 28, 532.

Blaxland, J. D. \& Fincham, I. H. (1950). Mycosis of the crop (moniliasis) in poultry. Brit. vet. J. 106, 221.

Boinin, J. \& Abadie, F. (1954). Les levures des liqueurs tannantes végétales; leur action sur les tannins pyrogalliques. Bull. Soc. mycol. Fr. 70, 353.

Burkey, L. A., Buckner, C. R., Underwood, P. C. \& Swett, W. W. (1951). Trends in the incidence of mastitis infections by different organisms. U.S. Dep. Agric. BDI-Inf-129.

Coltelen, F. \& Cochet, G. (1942). Les rongeurs domestiques réservoirs de virus en mycopathologie humaine et vétérinaire. Ann. Parasit. hum. comp. 19, 85.

Di Menna, M. E. (1955). A search for pathogenic species of yeasts in New Zealand soils. J. gen. Microbiol. 12, 54 .

el Tabey Simenata, A. M., Mrak, E. M. \& Phaff, H. J. (1955). Yeasts isolated from Drosophila and their suspected feeding places in southern and central California. Mycologia, 67, 799.

Emmons, C. W. (1951). Isolation of Cryptococcus neoformans from soil. J. Bact. 62, 685.

Emmons, C. W. (1955). Saprophytic sources of Cryptococcus neoformans associated with the pigeon (Columba livia). Amer. J. Hyg. 62, 227.

Jordan, F. T. W. (1953). The incidence of Candida albicans in the crops of fowls. Brit. vet. J. 109, 527.

Lernau, Сh., Shapiro, A. \& Aschner, M. (1947). Yeast infection of udder after irrigation with penicillin. Refuah. vet. 4,36 .

Lodder, J. \& Kreger-van RiJ, N. J. W. (1952). The Yeasts. Amsterdam: North Holland Publishing Company.

Lopez Fernandez, J. R. (1952). Acción patógena y experimental de la levadura Torulopsis glabrata (Anderson, 1917) Lodder y de Vries, productora de lesiones histopatológicas semejantes a las de la histoplasmosis. Ann. Fac. Med. Montevideo, 37, 470. 
Mackinnon, J. E. (1936). Caracteres y grado de la virulencia experimental de las torulopsidaceas de la sub-familia micotoruleas (monilias). Ann. Fac. Med. Montevideo, 21, 320.

Marples, M. J. \& Di Menna, M. E. (1952). The incidence of Candida albicans in Dunedin, New Zealand. J. Path. Bact. 64, 497.

Murphy, J. M. \& Drake, C. H. (1947). Infection of the bovine udder with yeast-like fungi. Amer. J. vet. Res. 8, 43.

Negroni, P. \& Fisher, I. (1941). Contribucion al conocimiento de la flora micologica (microfitos) del delta del parana. Rev. Inst. bact., Malbrán, 10, 334.

Phaff, H. J. (1956). A proposal for amendment of the diagnosis of the genus Pichia Hansen. Leeuwenhoek ned. Tijdschr. 22, 113.

Phaff, H. J., Mrak, E. M. \& Williams, O. B. (1952). Yeasts isolated from the shrimp. Mycologia, 44, 431.

Phaff, H. J., Miller, M. W. \& Shifrine, M. (1956). The taxonomy of yeasts isolated from Drosophila in the Yosemite region of California. Leeuwenhoek ned. Tijdschr. 22, 145.

Pounden, W. D., Amberson, E. M. \& Jaeger, A. B. (1952). A severe mastitis problem associated with Cryptococcus neoformans in a large dairy herd. Amer. J. vet. Res., 47, 121.

RoLıs, M. (1934). Hefe als Ursache für Euterentzündungen bei Kühen. Dtsch. tierärztl. Wschr. 42, 385.

Shifrine, M. \& Phaff, H. J. (1956). The association of yeasts with certain bark beetles. Mycologia, 48, 41.

Simon, J., Nichols, R. E. \& Morse, E. V. (1953). An outbreak of bovine cryptococcosis. J. Amer. vet. med. Ass. 122, 31.

Skinner, C. E. (1947). The yeast-like fungi: Candida and Brettanomyces. Bact. Rev. $11,227$.

STUART, P. (1951). An outbreak of bovine mastitis from which yeasts were isolated, and attempts to reproduce the conditions experimentally. Vet. Rec. 63, 314.

Talice, R. V. (1932). Parasitisme des hérissons par les mycotorulées. Ann. Parasit. hum. comp. 10, 81.

Uden, N. van (1952). Zur Kenntnis von Torulopsis pintolopesii sp.nov. Arch. Microbiol. 17, 199.

Uden, N. van (1956). Rapid method for testing raffinose fermentation by yeasts. J. Bact., 72, 793.

Uden, N. van, Matos Faia, M. de \& Assis-Lopes, L. (1956). Isolation of Candida albicans from vegetable sources. J. gen. Microbiol. 15, 151.

White, J. (1954). Yeast Technology. New York: John Wiley and Sons Inc.

Wickerham, L. J. (1951). Taxonomy of yeasts. Tech. Bull. U.S. Dep. Agric. no. 1029.

Yo Bwan HIE (1954). Vulvovaginitis mycotica in the zwangerschap. Thesis, University of Utrecht, Holland. 